\title{
Penerapan Gelombang Plasma dalam Mengurangi Kadar Chemical Oxygen Demand (COD) pada Limbah Batik Melalui Corona Plasma dan Elektrokoagulasi dengan Metode Variasi
}

\author{
Valentinus Galih Vidia Putra' ${ }^{1}$, Juliany Ningsih Mohamad², Yusril Yusuf ${ }^{3}$ \\ ${ }^{1}$ Department of Textile Engineering, Politeknik STTT Bandung, Bandung, Indonesia \\ ${ }^{2}$ Department of Physics, Universitas Nusa Cendana, Kupang, Indonesia \\ ${ }^{3}$ Department of Physics, Universitas Gadjah Mada, Yogyakarta, Indonesia
}

\section{Info Artikel}

\section{Histori Artikel:}

Diterima: 31 Maret, 2020

Direvisi:14 Juni, 2020

Diterbitkan: 1 September, 2020

\section{Kata kunci:}

kadar COD

Elektrokoagulasi

Plasma

Pengolahan air limbah

Tekstil

\section{Keywords: \\ COD level \\ Electrocoagulant \\ plasma \\ waste water treatment \\ textile}

\section{Penulis Korespondensi:}

Valentines Galih Vidia Putra valentinus@kemenperin.go.id

\begin{abstract}
ABSTRAK
Proses pengolahan limbah tekstil umumnya dapat berupa limbah dari proses penghilangan kanji (Desizing), penggelantangan (Scouring), pemutihan (Bleaching), dan pencelupan kain (Dyeing) serta proses pewarnaan dan pembilasan yang menghasilkan air limbah berwarna dengan COD yang tinggi. Dikarenakan kompleksitas jenis limbah tekstil, maka pemilihan metode pengolahan limbah merupakan suatu tantangan tersendiri dalam penelitian oleh beberapa peneliti. Artikel ini memperlihatkan beberapa metode pengolahan limbah dengan menggunakan metode elektrokoagulan (EC), metode plasma dan gabungan metode plasma dan elektrokoagulan. Hasil riset memperlihatkan bahwa pengabungan metode plasma dan elektrokoagulan akan lebih baik dalam penguraian air limbah dengan indikator menurunnya COD pada limbah (sebesar 240mgO2/L hingga $250 \mathrm{mgO} / \mathrm{L}$ ). Efisiensi pada metode plasmaelektrokoagulasi sebesar $42,5 \%-44,8 \%$.
\end{abstract}

The processing of textile waste can generally be in the form of waste from the process of desizing, bleaching, Scouring, and Dyeing as well as the staining and rinsing process that produces colored wastewater with high Chemical Oxygen Demand (COD). Due to the complexity of the types of textile waste, the selection of waste treatment methods is a challenge in research by several researchers. This article shows several waste treatment methods using the electrocoagulant (EC) method, the plasma method and the combined plasma and electrocoagulant method. The results of the research show that combining the plasma and electrocoagulant methods will be better in the decomposition of wastewater with indicators of decreasing COD in waste (240mg $\mathrm{O}_{2} / \mathrm{L}$ to $\left.250 \mathrm{mgO}_{2} / \mathrm{L}\right)$. Efficiency in the plasma-electrocoagulation method is $42.5 \%-44.8 \%$.

\section{PENDAHULUAN}

Penerapan ilmu fisika dalam berbagai bidang telah banyak dilakukan oleh banyak peneliti, Murti \& Putra (2020) dan Putra \& Wijayono (2019) telah mengimplementasikan penerapan ilmu fisika plasma pada bidang tekstil dengan menggunakan prinsip gelombang plasma untuk memodifikasi sifat mekanik dan fungsional material tekstil melalui proses perubahan struktur permukaan kain serta gugus fungsi material tanpa menggunakan bahan kimia anorganik dalam rangka untuk mengurangi limbah cair dari zat kimia tekstil. Menurut Putra \& Wijayono (2019) serta Murti \& Putra (2020), bidang fisika 
Putra dkk.: Penerapan Gelombang Plasma dalam Mengurangi Kadar Chemical Oxygen Demand (COD) pada Limbah Batik Melalui Corona Plasma dan Elektrokoagulasi dengan Metode Variasi

plasma diharapkan mampu mempelopori perkembangan teknologi baru dalam penyelesaian masalah tekstil, khususnya pada permasalahan limbah tekstil dan rekayasa material tekstil. Kalliala dan Talvenmaa (2000) serta Amril (2015) menyatakan bahwa pertumbuhan industri tekstil di dunia mempunyai hubungan timbal balik terhadap tingkat perekonomian suatu negara dan timbulnya angka pencemaran terhadap suatu lingkungan hidup yang cukup tinggi. Kalliala \& Talvenmaa (2000) dan Bilińska, Gmurek, Ledakowicz \& Bilińska (2017) juga menyatakan bahwa limbah tekstil yang mengandung pollutant perlu dilakukan pengolahan sebelum dibuang ke lingkungan. Limbah cair merupakan limbah yang paling banyak dihasilkan dalam industri tekstil dan paling berpotensi menimbulkan pencemaran lingkungan. Proses produksi industri tekstil yaitu penghilangan kanji (desizing), penggelantangan kain (scouring), pemucatan (bleaching), dan pencelupan (dyeing) serta proses pewarnaan (coloring) dan pembilasan yang menghasilkan air limbah berwarna dengan kandungan kadar Chemical Oxygen Demand atau COD yang tinggi, serta warna yang keruh. COD adalah jumlah oksigen yang dibutuhkan untuk mengoksidasi zat organik maupun zat anorganik yang terdapat dalam suatu limbah cair tekstil dengan memanfaatkan suatu oksidator yaitu kalium dikromat sebagai sumber oksigen. Nilai COD atau Chemical Oxygen Demand adalah besaran untuk pencemaran air oleh zat organik dan zat anorganik yang secara alamiah dapat dioksidasi melalui proses biologis dan dapat mengakibatkan berkurangnya oksigen terlarut dalam air. Zat yang tersuspensi dalam air limbah tekstil secara umum adalah suatu zat organik dan zat anorganik yang terkandung dalam air dan zat tersebut adalah salah satu penyebab kekeruhan pada cairan dan mengakibatkan larutan tersebut akan menghalangi sinar matahari masuk ke dalam dasar cairan tersebut Darmawanti (2010) dan Sucipta (2019).

Darmawanti (2010) menyatakan bahwa Industri batik merupakan salah satu industri yang menggunakan zat warna dengan kadar yang tinggi serta sisa zat warna tersebut biasanya dibuang ke lingkungan sebagai limbah cair. Menurut Darmawanti (2010), hasil buangan proses pewarnaan batik ini menimbulkan dampak yang merugikan terhadap lingkungan dikarenakan keterbatasan lingkungan untuk mendegradasi zat warna tersebut Darmawanti (2010) menyatakan bahwa limbah cair dari proses pewarnaan dan pencelupan batik di tekstil merupakan salah satu sumber pencemaran lingkungan air yang tinggi saat tidak dilakukan pengolahan limbah. Analisis karakteristik sampel limbah dilakukan terlebih dahulu sebagai gambaran awal kondisi limbah yang akan diolah. Teknologi pengolahan limbah batik cair secara biologi, kimia, fisika maupun kombinasi antara ketiga proses tersebut dapat digunakan untuk mengolah limbah cair industri batik. Darmawanti (2010) menyatakan bahwa pengolahan limbah cair dengan proses biologi misalnya dengan menggunakan mikroorganisme telah banyak diterapkan untuk mereduksi senyawa organik limbah cair industri batik namun hasil pengolahannya tidak terlalu baik dikarenakan zat warna mempunyai sifat tahan terhadap degradasi biologi. Beberapa peneliti, seperti Zongo, Maiga, Wéthé, Valentin,. Leclerc, Paternotten \& Lapicque (2009), Sakthisharmila, Palanisamy \& Manikandan (2018), menggunakan metode fisika yaitu dengan menggunakan penerapan elektrokimia seperti elektrokoagulasi yang berfungsi untuk menghilangkan warna pada pengolahan limbah cair tekstil namun kelemahan dari pengolahan limbah tersebut adalah diperlukannya biaya yang cukup tinggi pada material elektroda, hal senada juga dilakukan oleh Chafi, Gourich, Essadki, Vial \& Fabregat (2011) yang telah melakukan pengolahan limbah menggunakan metode elektrokoagulan. Hasil yang didapatkan memperlihatkan bahwa terdapat penurunan kadar COD pada air limbah batik tekstil namun tidak terlalu signifikan serta efisien dalam pengolahan limbah. Menurut beberapa peneliti seperti Dors, Metel, Mizeraczyk \& Phenol (2007), Sunka Babicky, Clupek, Lukes, Simek, Schmidt dan Cernak (1999), Sato dan Yasuoka (2008), Locke, Sato, Sunka, Hoffmann dan Chang (2006), Bilińska, Gmurek \& Ledakowicz (2015 ), Lukes dan Locke (2005) untuk mengatasi masalah pengolahan limbah cair diperlukan alternatif baru untuk mengolah limbah cair industri tekstil yang efektif dan efisien dalam menurunkan polutan organik dan zat warna. Salah satu alternatif yang dapat digunakan adalah teknologi plasma. Menurut beberapa peneliti Dors, Metel, Mizeraczyk, Phenol (2007), Sunka, Babicky, Clupek, Lukes, Simek, Schmidt dan Cernak (1999), Sato dan Yasuoka (2008), Locke, Sato, Sunka, Hoffmann dan Chang (2006),, Lukes dan Locke (2005) teknologi plasma tidak menggunakan bahan kimia dalam pengolahan limbah dikarenakan teknologi plasma hanya menggunakan proses kelistrikan dengan tegangan tinggi dengan hasil pengolahan 
limbah cair tekstil akan lebih baik dikarenakan teknologi ini akan menghasilkan limbah lumpur yang lebih sedikit dibandingkan metode elektrokoagulasi ataupun metode kimia dan biologi, selain itu teknologi plasma, lebih praktis dalam operasional serta tidak membutuhkan lahan yang luas. Faktor penting dalam proses pembentukan lucutan atau electrical discharge adalah tegangan listrik yang digunakan. Metode ini dapat menyisihkan partikel tersuspensi, logam-logam berat, kekeruhan dan warna. Menurut Kobya, Can dan Bayramoglu (2003), Şengil dan Özacar (2009) Metode pengolahan limbah dengan elektrokoagulasi adalah suatu metode pengolahan limbah cair dengan menggunakan sumber arus langsung dari dua elektroda logam yang dimasukkan ke dalam air limbah. Proses elektrokoagulasi merupakan gabungan dari proses elektrokimia dan proses flokulasi-koagulasi. Kobya, Can,. dan Bayramoglu (2003), Şengil dan Özacar (2009) menyatakan bahwa metode elektrokoagulasi telah banyak dikaji oleh banyak peneliti dalam pemrosesan air limbah tekstil. Tujuan dari penelitian ini adalah untuk mencari metode proses penguraian limbah tekstil yang memiliki efisiensi penurunan kadar COD tertinggi pada limbah industri tekstil baik menggunakan teknologi gelombang plasma, elektrokoagulsi maupun kombinasi keduanya.

\section{METODE PENELITIAN}

Pada metode penelitian dijealskan mengenai alat dan bahan pada penelitian ini serta tahapan penelitian yang meliputi tiga tahap yaitu: tahap persiapan penelitian, tahap pelaksanaan penelitian, dan tahap analisis data penelitian.

\subsection{Alat dan Bahan}

Alat dan bahan yang digunakan pada penelitian ini adalah:

1. Prototipe Generator Plasma Pijar Korona Multi Titik-Bidang, Laboratorium Fisika-Mekatronika, Politeknik STTT Bandung, Jawa Barat, Indonesia dengan spesifikasi :

a. Jenis plasma dingin non thermal dengan tekanan atmosfer

b. Gas yang digunakan gas di udara sekitar (ambient air)

c. Input tegangan $=0-220$ Volt $(\mathrm{AC})$

d. Output tegangan $=0-30 \mathrm{kV}(\mathrm{DC})$

e. Elektoda multi titik-bidang

2. Prototipe alat elektrokoagulasi, Laboratorium Fisika-Mekatronika, Politeknik STTT Bandung, Jawa Barat, Indonesia dengan spesifikasi :

a. Lempeng elektroda berjumlah dua buah dengan bahan plat tembaga tipis

b. Jenis tegangan listrik output sebesar 5-15 volt DC

c. Sumber listrik PLN 0-220 volt AC

Bahan contoh uji limbah tekstil cair adalah sampel limbah cair industri tekstil yang diambil dari hasil buangan limbah batik cair langsung dari laboratorium pencelupan tekstil Politeknik STTT Bandung, Jawa Barat, Indonesia dengan spesifikasi warna secara visual berwarna hitam keruh dan kadar COD rerata $435 \pm 10\left(\mathrm{mg} \mathrm{O}_{2} / \mathrm{L}\right)$.

\subsection{Tahap Persiapan}

Tahap persiapan terdiri dari pengambilan contoh uji limbah tekstil cair, uji karakteristik awal contoh uji limbah tekstil cair, uji coba alat generator plasma multititik dan alat elektrokoagulasi. Bahan contoh uji atau sampel limbah cair industri tekstil diambil dari hasil buangan limbah batik cair langsung dari laboratorium pencelupan tekstil Politeknik STTT Bandung, Jawa Barat, Indonesia. Analisis karakteristik sampel limbah (nilai COD) dilakukan terlebih dahulu sebagai gambaran awal kondisi limbah yang akan diolah di laboratorium Kimia Analisa Politeknik STTT Bandung, Jawa Barat, Indonesia. Parameter yang diuji adalah nilai COD dan kemudian dilakukan uji coba alat pengolah limbah di laboratorium Fisika-Mekatronika Politeknik STTT Bandung, Jawa Barat, Indonesia. Uji coba alat pengolah limbah dimaksudkan untuk mengetahui kinerja alat dengan baik, 
sesuai dengan prinsip kerja dalam beberapa literatur. Cara uji coba dengan menjalankan alat plasma dan elektrokoagulasi pada penelitian ini antara lain:

1. Pembacaan tegangan pada sumber tegangan DC untuk plasma saat timbulnya lucutan plasma.

2. Pengujian adanya arus pada lempengan elektroda untuk metode elektrokoagulasi

\subsection{Tahap Pelaksanaan Penelitian}

Proses pengolahan limbah dengan menggunakan generator plasma multi titik selama 30 menit dengan tegangan $8 \mathrm{kV}$ yang dilakukan di Laboratorium Fisika-Mekatronika Politeknik STTT Bandung, Jawa Barat, Indonesia. Pada penelitian ini, plasma dibentuk dalam fase gas lingkungan (ambient) yang membutuhkan tegangan listrik $8 \mathrm{kV}$ serta ketinggian air dijaga agar permukaan air kontak langsung dengan elektroda. Rangkaian alat disusun sebelum dilakukan proses pengolahan. Pada penelitian ini rangkaian alat ditunjukkan seperti pada Gambar 1

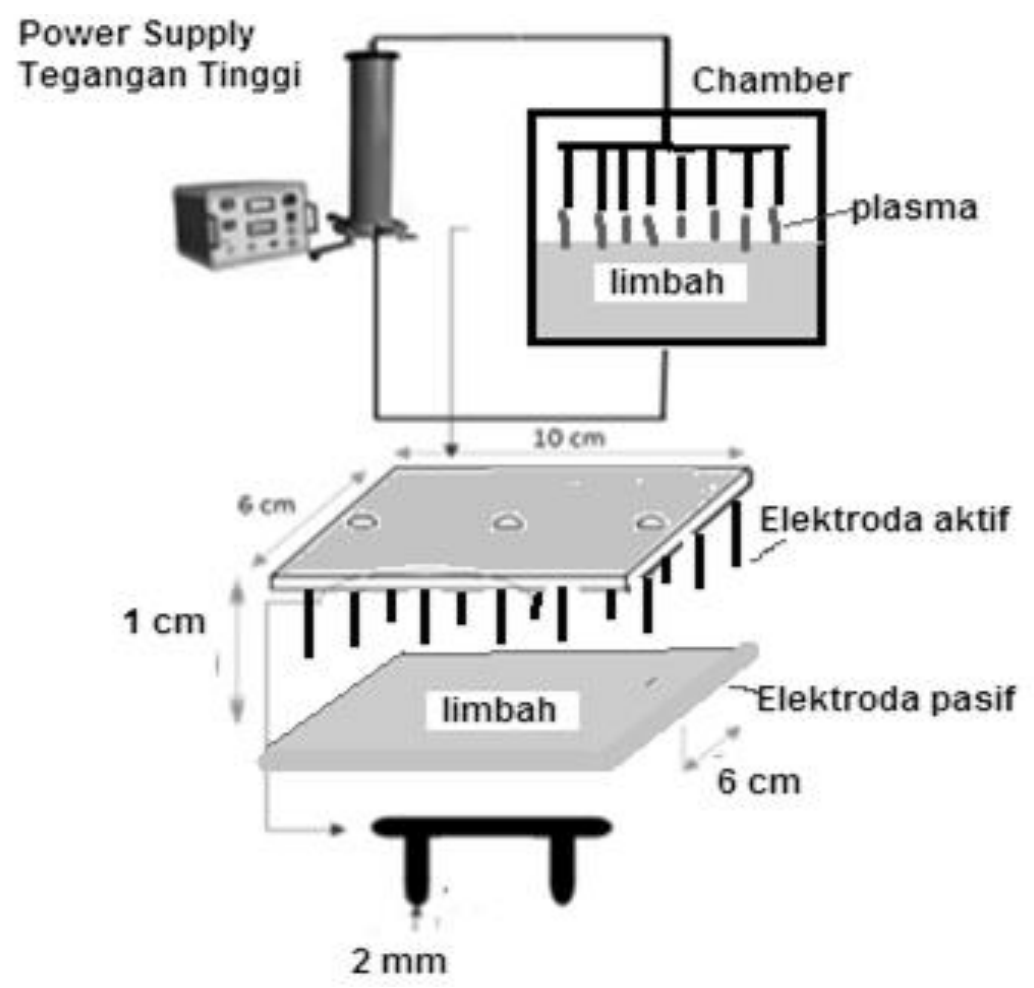

Gambar 1 Skema Reaktor Plasma

Berdasarkan Gambar 1, limbah cair tekstil ditempatkan pada wadah limbah dan diletakan pada chamber reaktor plasma selama 30 menit dengan konfigurasi multititik datar. Tegangan masukan diatur melalui sumber tegangan listrik AC yangmana besar tegangan akan muncul pada instrument dan diatur dengan menggunakan variac agar mendapatkan tegangan keluaran $8 \mathrm{kV}$ DC.

Pengolahan limbah cair tekstil dilakukan juga dengan metode elektrokoagulasi selama 30 menit dengan tegangan listrik DC 5 Volt, dengan menggunakan lempengan tembaga sebagai elektroda kerja. Skema rangkaian alat elektrokoagulasi adalah sebagai berikut (Gambar 2): 


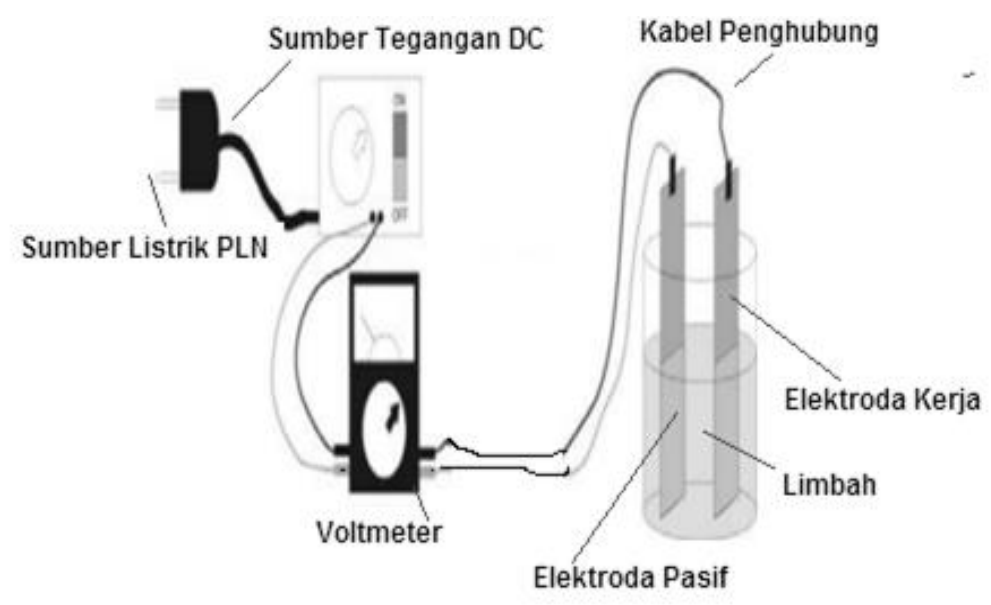

Gambar 2 Skema Metode Elektrokoagulasi

\subsection{Tahap Analisis Data}

Analisis data meliputi analisis dengan diagram untuk memperlihatkan tingkat penurunan konsentrasi COD dengan urutan metode yang berbeda serta perhitungan nilai efisiensi metode pengolahan limbah dalam penurunan kadar COD. Pengukuran COD dari contoh uji limbah cair tekstil yang sudah diolah dilakukan di laboratorium Kimia Analisa Politeknik STTT Bandung. Untuk menentukan besar efisiensi setiap metode maka dapat dilakukan dengan menggunakan perhitungan efisiensi pada persamaan (1) di bawah

$$
\eta=\frac{C O D_{a w a l}-C O D_{a k h i r}}{C O D_{a w a l}} \times 100 \%
$$

\section{HASIL DAN PEMBAHASAN}

Berdasarkan hasil penelitian didapatkan besar diagram penurunan COD dari sampel awal COD sebelum dilakukan pengolahan limbah sebesar $440 \pm 10 \mathrm{mg} \mathrm{O}_{2} / \mathrm{L}$ pada berbagai metode baik menggunakan teknologi plasma, elektrokoagulsi maupun kombinasi keduanya seperti pada Gambar 3 di bawah.

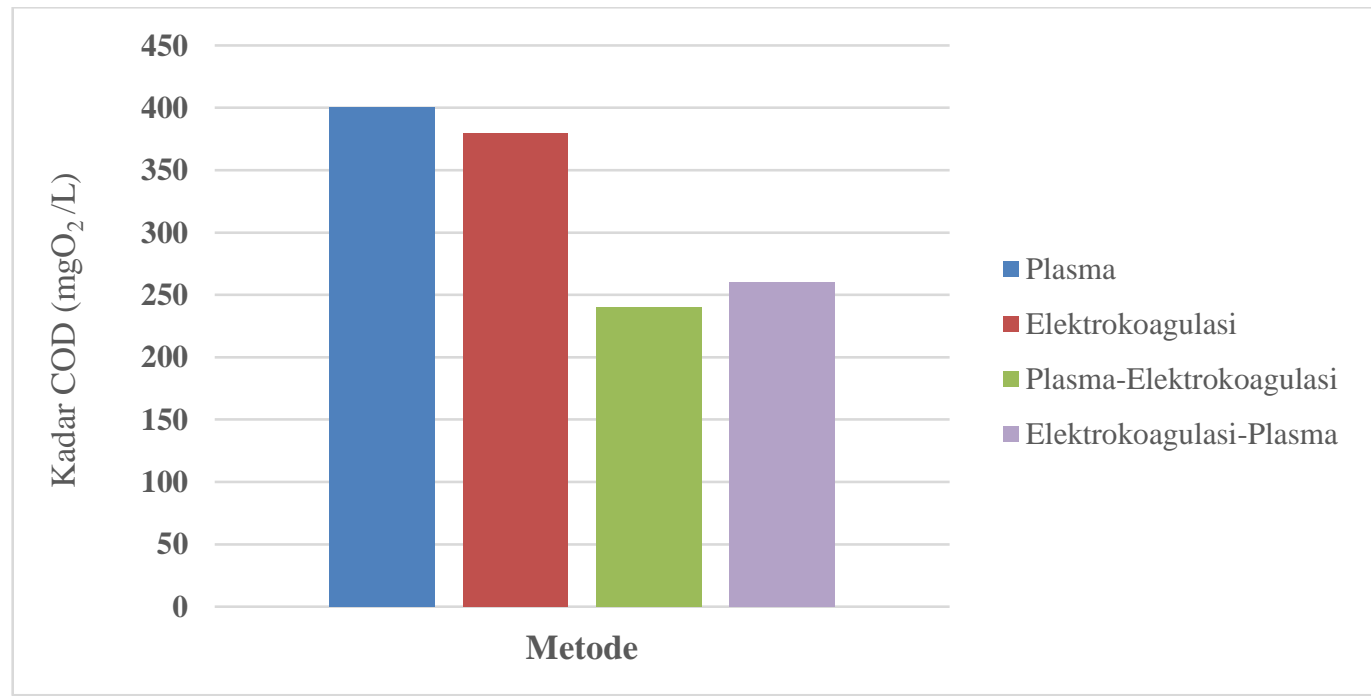

Gambar 3 Penurunan Kadar COD pada Beberapa Metode 
Putra dkk.: Penerapan Gelombang Plasma dalam Mengurangi Kadar Chemical Oxygen Demand (COD) pada Limbah Batik Melalui Corona Plasma dan Elektrokoagulasi dengan Metode Variasi

Analisis karakteristik awal sampel limbah tekstil beserta baku mutu yang telah diuji di laboratorium Kimia Analisa Politeknik STTT Bandung dapat diperlihatkan pada tabel 1 di bawah

Tabel 1. Data Hasil Uji Karakteristik Awal Sampel Limbah

\begin{tabular}{cccc}
\hline Percobaan ke & Parameter & Hasil Analisa COD & Baku mutu COD \\
\hline 1 & COD & $440\left(\mathrm{mg} \mathrm{O}_{2} / \mathrm{L}\right)$ & $250\left(\mathrm{mg} \mathrm{O}_{2} / \mathrm{L}\right)$ \\
\hline 2 & COD & $430\left(\mathrm{mg} \mathrm{O}_{2} / \mathrm{L}\right)$ & $250\left(\mathrm{mg} \mathrm{O}_{2} / \mathrm{L}\right)$ \\
\hline $\begin{array}{c}\text { Rerata hasil } \\
\text { percobaan }\end{array}$ & COD & $435 \pm 10\left(\mathrm{mg} \mathrm{O}_{2} / \mathrm{L}\right)$ & $250\left(\mathrm{mg} \mathrm{O}_{2} / \mathrm{L}\right)$ \\
\hline
\end{tabular}

Berdasarkan tabel 1 di atas, dapat diperlihatkan bahwa kadar COD awal dari sampel memiliki kecnderungan melebihi standar baku mutu yang berlaku yaitu sebesar 250 ( $\mathrm{mg} \mathrm{O}_{2} / \mathrm{L}$ ) yang mengindikasikan bahwa sampel air limbah tekstil dalam keadaan keruh dengan besar rerata hasil percobaan sebesar $435 \pm 10\left(\mathrm{mg} \mathrm{O}_{2} / \mathrm{L}\right)$. Berdasarkan hasil penelitian didapatkan besar nilai COD pada berbagai metode baik menggunakan teknologi plasma, elektrokoagulsi maupun kombinasi keduanya seperti pada tabel 2

Tabel 2. Data Hasil Uji Karakteristik Hasil Pengolahan Limbah

\begin{tabular}{ccc}
\hline Metode & Parameter & Hasil analisa COD \\
\hline Elektrokoagulasi & COD & $380 \pm 10\left(\mathrm{mg} \mathrm{O}_{2} / \mathrm{L}\right)$ \\
Elektrokoagulasi-plasma & COD & $250 \pm 10\left(\mathrm{mg} \mathrm{O}_{2} / \mathrm{L}\right)$ \\
Plasma -elektrokoagulasi & COD & $240 \pm 10\left(\mathrm{mg} \mathrm{O}_{2} / \mathrm{L}\right)$ \\
Plasma & COD & $400 \pm 10\left(\mathrm{mg} \mathrm{O}_{2} / \mathrm{L}\right)$ \\
\hline
\end{tabular}

Dengan menggunakann persamaan (1), maka hasil efisiensi dengan metode plasma didapatkan sebesar $\eta=8.1 \%$, Hasil efisiensi dengan metode elektrokoagulasi didapatkan sebesar $\eta=12.6 \%$, Hasil efisiensi dengan metode teknologi plasma dan diikuti dengan elektrokoagulasi didapatkan sebesar $\eta=44.8 \%$, dan Hasil efisiensi dengan metode elektrokoagulasi dan diikuti dengan teknologi plasma didapatkan sebesar $\eta=42.5 \%$. pada penelitian ini juga dikaji hasil visual pada setiap metode. Hasil tampilan visual perbandingan warna sampel dengan pengolahan limbah cair dengan metode paparan plasma dengan nilai COD sebesar $400 \pm 10\left(\mathrm{mgO}_{2} / \mathrm{L}\right)$ diperlihatkan pada gambar 4

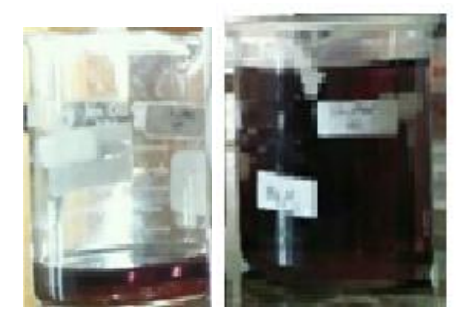

Gambar 4. Perbandingan warna hasil plasma dengan sampel (warna ungu untuk perlakuan dengan plasma dan warna hitam untuk sampel)

Hasil tampilan visual perbandingan warna sampel dengan pengolahan limbah cair dengan metode elektrokoagulan dengan nilai COD sebesar $380 \pm 10\left(\mathrm{mgO}_{2} / \mathrm{L}\right)$ dapat dilihat pada gambar 5 di bawah 


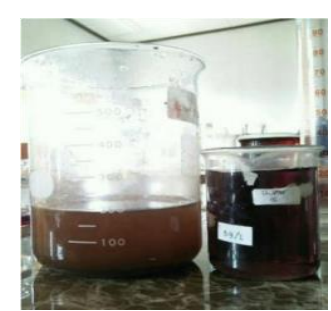

Gambar 5. Perbandingan warna hasil elektrokoagulan dengan sampel (warna coklat untuk perlakuan dengan elektrokoagulan dan warna hitam untuk sampel)

Hasil tampilan visual perbandingan warna sampel dengan pengolahan limbah cair dengan metode elektrokoagulasi dan dilanjutkan plasma (elektrokoagulan-plasma) dengan nilai COD sebesar $250 \pm 10\left(\mathrm{mgO}_{2} / \mathrm{L}\right)$ serta metode plasma-elektrokoagulan dengan nilai COD sebesar $240 \pm 10\left(\mathrm{mgO}_{2} / \mathrm{L}\right)$ dapat dilihat pada gambar 6 dan gambar 7
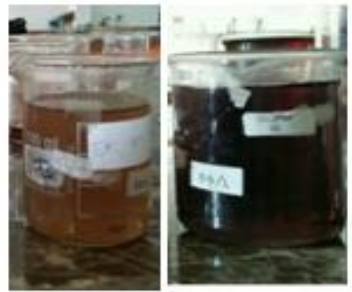

Gambar 6. Perbandingan warna hasil metode elektrokoagulasi dan dilanjutkan plasma dengan sampel (warna coklat bening untuk perlakuan dengan metode elektrokoagulasi dan dilanjutkan plasma dan warna hitam untuk sampel)

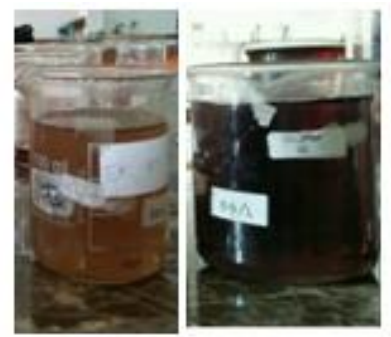

Gambar 7. Perbandingan warna hasil metode plasma dilanjutkan dengan elektrokoagulasi dengan sampel (warna coklat bening untuk perlakuan dengan metode plasma dan dilanjutkan dengan elektrokoagulasi dan warna hitam untuk sampel)

Berdasarkan hasil eksperimen dan analisa data maka dapat dijelaskan kelebihan dan kelemahan beberapa metode pengolahan limbah sebagai berikut:

\subsection{Metode 1 (teknologi plasma)}

Pada pengolahan limbah menggunakan metode plasma, penurunan kadar COD yang dihasilkan

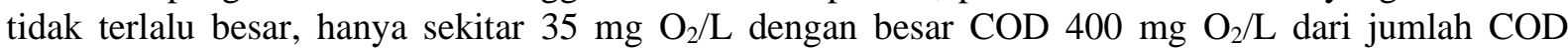
sampel awal sekitar $435 \mathrm{mg} \mathrm{O} / \mathrm{L}$. Hal ini dapat terjadi karena pada proses plasma, senyawa organik yang terkandung di dalam limbah hanya diuraikan saja sehingga hasilnya tidak terlalu signifikan. Teknologi plasma berfungsi sebagai proses pengoksidasian senyawa organik. Aksi reaksi yang terjadi dalam reaktor plasma adalah terbentuknya ion positif, ion negatif, radikal, sinar ultraviolet (UV) dan elektron dalam reaktor plasma pada limbah cair industri. Adanya sinar ultraviolet (UV) dan pergerakan ion serta elektron akan mengakibatkan molekul air $\left(\mathrm{H}_{2} \mathrm{O}\right)$ akan terurai dan menghasilkan spesies aktif seperti $\mathrm{OH}, \mathrm{O}, \mathrm{H}$ dan $\mathrm{H}_{2} \mathrm{O}_{2}$. Spesies aktif tersebut merupakan oksidan kuat yang dapat mengoksidasi berbagai senyawa organik sekaligus membunuh bakteri dalam limbah cair tersebut, spesies aktif tersebut kemudian bereaksi dengan unsur karbon $(\mathrm{C})$, hidrogen $(\mathrm{H})$, oksigen $(\mathrm{O})$, nitrogen 
$(\mathrm{N})$, dan sulfur (S) yang terdapat dalam limbah cair industri tekstil. Tumbukan elektron dan ion dengan molekul air limbah mengakibatkan terjadi reaksi kimia melalui oksidasi dan reduksi yang dapat menguraikan limbah tekstil. Metode ini hanya memiliki efisiensi sebesar $8.1 \%$. kelemahan dari metode ini adalah metode ini tidak efektif untuk menurunkan kadar COD limbah cair tekstil dan memiliki efisiensi yang rendah serta tegangan listrik yang dibutuhkan dalam skala kilovolt, namun keuntungan dari metode ini adalah piranti yang digunakan dalam pengolahan limbah ini tidak membutuhkan suatu elektroda logam yang besar seperti pada metode elektrokoagulan.

\subsection{Metode 2 (elektrokoagulasi)}

Pada pengolahan limbah menggunakan metode elektrokoagulasi, penurunan kadar COD yang

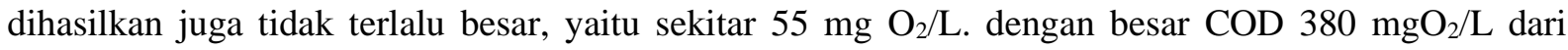
jumlah COD sampel awal sekitar $435 \mathrm{mg} \mathrm{O}_{2} / \mathrm{L}$. Hal ini dapat terjadi karena pada proses elektrokoagulasi, senyawa organik yang dibentuk masih memiliki ukuran yang cukup besar sehingga tidak terlalu dapat terurai secara baik. Pada pengolahan limbah menggunakan elektrokoagulasi, proses pengolahan adalah proses destabilisasi suspensi, emulsi dan larutan yang mengandung polutan, yaitu melalui suatu cara dengan mengalirkan arus listrik searah (DC) melalui limbah cair sehingga terbentuk gumpalan yang mudah dipisahkan. Metode ini memiliki hasil efisiensi sebesar 12,6\%. Kelemahand ari metode ini adalah metode ini memiliki efisiensi yang rendah dan juga metode ini memerlukan suatu elektroda logam yang cukup besar, namun keuntungan dari metode ini adalah listrik yang digunakan memiliki tegangan yang rendah dan tidak berbahaya.

\subsection{Metode 3 (plasma-elektrokoagulasi)}

Pada pengolahan limbah menggunakan metode plasma-elektrokoagulasi, penurunan kadar COD yang dihasilkan cukup besar, yaitu sebesar $195 \mathrm{mg} \mathrm{O} / \mathrm{L}$ dengan besar COD $240 \mathrm{mgO}_{2} / \mathrm{L}$ dari jumlah COD sampel awal sekitar $435 \mathrm{mg} \mathrm{O}_{2} / \mathrm{L}$. Hal ini dapat terjadi karena pada proses plasmaelektrokoagulasi, senyawa organik yang terkandung di dalam limbah sudah diuraikan terlebih dahulu oleh spesies aktif seperti $\mathrm{OH}, \mathrm{O}, \mathrm{H}$ dan $\mathrm{H}_{2} \mathrm{O}_{2}$ yang muncul pada proses plasma sehingga pada saat proses elektrokoagulasi senyawa organik yang dibentuk menjadi flok lebih banyak karena ukuran partikel yang lebih kecil memudahkan terbentuknya flok. Metode ini memiliki efisiensi yang cukup besar yaitu sebesar $44,8 \%$. Keuntungan dari metode ini adalah metode ini memiliki efisiensi yang besar dalam mengurai limbah cair tekstil serta mampu menghasilkan penurunan kadar COD yang cukup besar, kelemahan dari metode ini adalah dibutuhkannya tegangan yang lebih besar dan piranti gabungan antara geneator plasma dan alat elektrokoagulan.

\subsection{Metode 4 (elektrokoagulasi-plasma)}

Pada pengolahan limbah menggunakan metode elektrokoagulasi-plasma, penurunan kadar COD yang dihasilkan cukup besar tetapi tidak sebesar pada metode plasma-elektrokoagulasi, yaitu sekitar

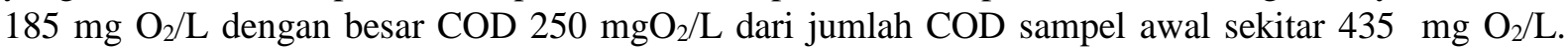
Hal ini dapat terjadi karena pada proses elektrokoagulasi, senyawa organik dibentuk menjadi flok, akan tetapi karena ukuran partikelnya masih cukup besar sehingga tidak semua senyawa organik terbentuk menjadi flok. Pada proses plasma, senyawa organik yang tidak terbentuk menjadi flok diuraikan. Pada metode ini, efisiensi yang dihasilkan sebesar 42,5\%. Keuntungan dari metode ini adalah metode ini memiliki efisiensi yang besar dalam mengurai limbah cair tekstil serta mampu menghasilkan penurunan kadar COD yang cukup besar, kelemahan dari metode ini adalah dibutuhkannya tegangan yang lebih besar dan piranti gabungan antara geneator plasma dan alat elektrokoagulan. Berdasarkan hasil penelitian didapatkan besar diagram efisiensi pada berbagai metode baik menggunakan teknologi plasma, elektrokoagulsi maupun kombinasi keduanya seperti pada gambar 8 . 


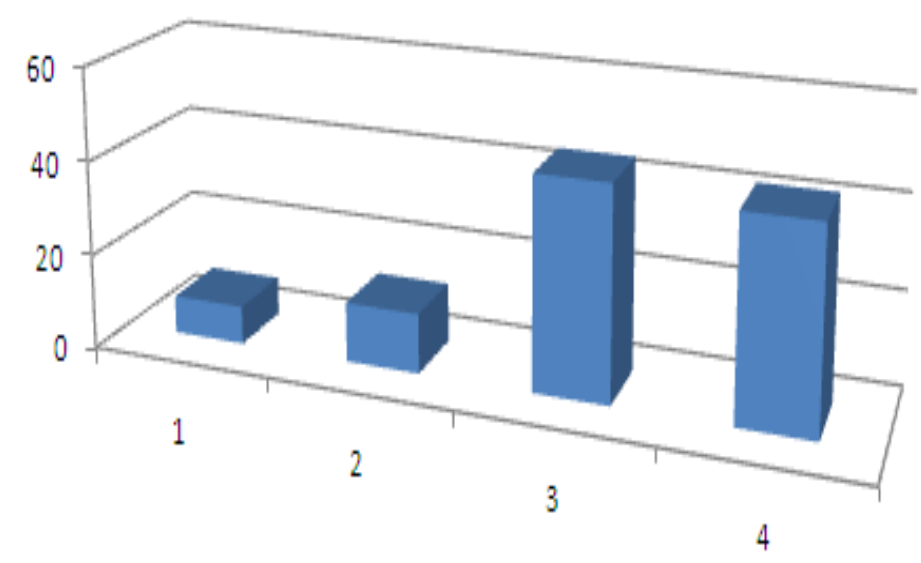

Gambar 8 Efisiensi penurunan kadar COD terhadap beberapa Metode: (1) Plasma; (2) Elektrokoagulasi; (3) Plasma-Elektrokoagulasi; (4) Elektrokoagulasi-Plasma

Hasil penelitian ini senada dengan hasil kajian dari beebrapa literature, yang menunjukkan bahwa teknologi palsma dan elektrokoagulan dapat digunakan untuk memproses air limbah tekstil. Menurut beberapa peneliti seperti, Dors, Metel, Mizeraczyk, Phenol (2007), Sunka, Babicky, Clupek, Lukes, Simek, Schmidt dan Cernak (1999), Sato dan Yasuoka (2008), Locke, Sato, Sunka, Hoffmann dan Chang J S, (2006), Teknologi plasma berfungsi sebagai proses pengoksidasian senyawa organik. Aksi reaksi yang terjadi dalam reaktor plasma adalah terbentuknya ion positif, ion negatif, radikal, sinar ultraviolet (UV) dan elektron dalam reaktor plasma pada limbah cair industri. Adanya sinar ultraviolet (UV) dan pergerakan ion serta elektron akan mengakibatkan molekul air $\left(\mathrm{H}_{2} \mathrm{O}\right)$ akan terurai dan menghasilkan spesies aktif seperti $\mathrm{OH}, \mathrm{O}, \mathrm{H}$ dan $\mathrm{H}_{2} \mathrm{O}_{2}$. Spesies aktif tersebut merupakan oksidan kuat yang dapat mengoksidasi berbagai senyawa organik sekaligus membunuh bakteri dalam limbah cair tersebut, spesies aktif tersebut kemudian bereaksi dengan unsur karbon $(\mathrm{C})$, hidrogen $(\mathrm{H})$, oksigen $(\mathrm{O})$, nitrogen $(\mathrm{N})$, dan sulfur $(\mathrm{S})$ yang terdapat dalam limbah cair industri tekstil. Tumbukan elektron dan ion dengan molekul air limbah mengakibatkan terjadi reaksi kimia melalui oksidasi dan reduksi. Pada pengolahan limbah menggunakan elektrokoagulasi, proses pengolahan adalah proses destabilisasi suspensi, emulsi dan larutan yang mengandung polutan, yaitu melalui suatu cara dengan mengalirkan arus listrik searah (DC) melalui limbah cair sehingga terbentuk gumpalan yang mudah dipisahkan. Metode elektrokoagulasi adalah suatu proses elektrolisis yang memerlukan sumber tenaga listrik dengan tegangan DC, penghantar listrik dan elektroda. Elektroda umumnya dapat terbuat dari aluminium, besi atau tembaga. Pada penelitian ini didapatkan bahwa efisiensi penurunan kadar COD yang terbesar didapatkan pada metode plasma dan elektrokoagulasi dengan efisiensi pada metode plasma-elektrokoagulasi sebesar $42,5 \%$ hingga $44,8 \%$.

\section{KESIMPULAN}

Berdasarkan hasil percobaan, dapat dilihat bahwa efisiensi penurunan kadar COD yang terbesar didapatkan pada metode plasma dan elektrokoagulasi. Hasil riset memperlihatkan bahwa pengabungan metode plasma dan elektrokoagulan akan lebih baik dalam penguraian air limbah dengan indikator menurunnya COD pada limbah. Efisiensi pada metode plasma-elektrokoagulasi sebesar $44,8 \%$. Hasil penelitian memperlihatkan bahwa metode plasma-elektrokoagulan maupun elektrokoagulan-plasma mampu mengolah limbah cair tekstil dengan lebih baik dengan efisiensi 42,5\% hingga 44,8\%. 
Putra dkk.: Penerapan Gelombang Plasma dalam Mengurangi Kadar Chemical Oxygen Demand (COD) pada Limbah Batik Melalui Corona Plasma dan Elektrokoagulasi dengan Metode Variasi

\section{UCAPAN TERIMA KASIH}

Penulis mengucapkan terima kasih kepada jurusan Teknik Tekstil Politeknik STTT Bandung dan juga Laboratorium Fisika Mekatronika Politeknik STTT Bandung yang telah mendukung kegiatan penelitian ini sehingga penelitian ini dapat diselesaikan dengan baik.

\section{DAFTAR PUSTAKA}

Amril, H. (2015). Teknologi Plasma untuk Pengolahan Air, Bandung: Institut Teknologi Bandung https://www.researchgate.net/publication/287699345Teknologi_Plasma_untuk_Pengolahan_Air. (diakses pada 2 Januari 2020)

Bilińska, L. Gmurek, M. Ledakowicz, S. (2015), Application of advanced oxidation technologies for decolorization dan mineralization of textile wastewaters, J. Adv. Oxid. Technol. 18

Bilińska, L. Gmurek, M. Ledakowicz, S. (2017), Textile wastewater treatment by AOPs for brine reuse, 9420 428. doi:10.1016/ j.psep.2017.04.019.

Chafi, M., Gourich, B., Essadki, A.H., dkk, (2011), Comparison of electrocoagulation using iron dan aluminium electrodes with chemical coagulation forthe removal of a highly soluble acid dye, Desalination. $281285-$ 292. doi:10.1016/J.DESAL.2011.08.004

Darmawanti, T. (2010). Pengolahan Limbah Cair Industri Batik dengan Metoda Elektrokoagulasi Menggunakan Besi Bekas Sebagai Elektroda .https://ejournal.undip.ac.id/index.php/ksa/article/vi ew/15662 (diakses pada 2 Januari 2020)

Dors, M., Metel, E. dan Mizeraczyk, J., (2007), Phenol Degradation in Water by Pulsed Streamer Corona Discharge dan Fenton Reaction, Int. J. Plasma Environ. Sci. Technol., 1, 76-81,

Hernaningsih, T. (2017). Tinjauan Teknologi Pengolahan Air Limbah Industri dengan Proses elektrokoagulasi. Jurnal Rekayasa Lingkungan, Vol 9 No 131-46

Kalliala, E., Talvenmaa, P., (2000), Environmental profile of textile wet processing in Finland, J. Clean. Prod. 8, 143-154. doi:10.1016/S0959-6526 (99) 00313-3.

Kobya, M. Can, O.T. Bayramoglu, M., (2003), Treatment of textile wastewaters by electrocoagulation using iron and aluminum electrodes, J. Hazard. Mater. 100 163-178. doi:10.1016/S0304-3894(03)00102-X

Locke B R, Sato M, Sunka P, Hoffmann M R dkk, (2006), Electrohydraulic discharge and nonthermal plasma, for water treatment Indust. Eng. Chem. Res. 45 882-905

Lukes P dan Locke B R (2005). Plasmachemical oxidation processes in a hybrid gas-liquid electrical discharge reactor J. Phys. D:Appl. Phys. 38 4074-81

Murti, W. \& Putra, VGV. (2020) Studi Pengaruh Perlakuan Plasma Terhadap Sifat Material Antibakteri Kain Kassa Menggunakan Minyak Atsiri (Zingiber Officinale Rosc), Jurnal Teori dan Aplikasi Fisika 8 (1), 69-76

Putra, V. G. V. \& Wijayono, A. (2019). Suatu Studi Awal Modifikasi Sifat Pembasahan Pada Permukaan Kain Tekstil Poliester 100\% Menggunakan Teknologi Plasma Pijar Korona, Prosiding Seminar Nasional Fisika (E-Journal), vol. 8, pp. 15-20,

Sakthisharmila, P Palanisamy, P.N dan Manikandan, P., (2018). Removal of benzidine based textile dye using different metal hydroxides generated in situ electrochemical treatment-A comparative study, J. Clean. Prod. 172 2206-2215.doi:10.1016/j.jclepro.2017.11.192

Sato K dan Yasuoka K .(2008). Pulsed discharge development in oxygen, argon, and helium bubbles in water IEEE Trans. PlasmaSci. 36 1144-5

Şengil, I.A. Özacar, M. (2009). The decolorization of C.I. Reactive Black 5 in aqueous solution by electrocoagulation using sacrificial iron electrodes, J. Hazard. Mater. 161 1369-1376. doi:10.1016/j.jhazmat.2008.04.100.

Sucipta, F. Studi Pengaruh Tegangan dan Flowrate Gas terhadap Konsentrasi COD dan Warna pada Limbah Cair Industri Tekstil dengan Teknologi Plasma. https://www.neliti.com/id/publications/191845/studi penurunan-cod-dan-warna-dengan-teknologiplasma-pada-limbah-cair-industri (diakses pada 2 Januari 2020)

Sunka P, Babicky V, Clupek M, dkk (1999). Generation of chemically active species by electrical discharges in water Plasma Sources Sci. Technol. 8 258-65

Zongo, I., Maiga, A.H., Wéthé, J., dkk (2009). Electrocoagulation for the treatment of textile wastewaters with $\mathrm{Al}$ or Fe electrodes: Compared variations of COD levels, turbidity and absorbance, J. Hazard. Mater. 169 70-76 doi:10.1016/j.jhazmat.2009.03.072 